\title{
高温気相反応による炭化珪素のコーティング
}

\author{
化学蒸着 (Chemical Vapor Deposition) に関する基礎的研究（第 1 報）
}

\author{
河嶋 千 尋・瀬 高 信 雄・中川順 吉 \\ （東京工業大学・工業材料研究所）
}

\section{Silicon Carbide Coatings by Vapor-Phase Reaction at High Temperature}

Fundamental Studies on Chemical Vapor Deposition (1)

By

Chihiro KAWASHIMA, Nobuo SETAKA and Junkichi NAKAGAWA

(Research Laboratory of Engineering Materials, Tokyo Institute of Technology, Tokyo)

Chemical vapor deposition was studied as early as in the years from 1922 to 1939 as a method of preparing high purity refractory metals and considerable progress in the fundamental studies and practical applications were carried out by Powell, Campbell and Gonser at The Battel Memorial Institute after 1955.

Some achievements of the auther's research have been applied already in Japan as a refractory coating for rocket nozzles and protective coating for nuclear graphites. However, chemical vapor deposition is promised to be of greater importance and interest in the future not only as the fundamentals of thermodynamics, crystalline growth but also a practical applications concerning with coating of nuclear fuel particles for fission product retention, epitaxially coated semi-conductor and whisker.

We have studied $\beta$-SiC coating by vapor-phase reaction of volatile silicon tetrachloride, toluen and hydrogen used as carrier gas which were induced onto the of surface graphite substrate heated by induction furnace. The composition of deposited layer was examined and identified mainly by $\mathrm{X}$-ray powder diffraction analysis method.

The experiment was carried out under the conditions at the ratio of $\mathrm{SiCl}_{4}$ and $\mathrm{C}_{7} \mathrm{H}_{8}$ varied between $1.3: 1$ and $5.0: 1$, the graphite substrate heated at the temperature ranging from $1200^{\circ}$ to $1500^{\circ} \mathrm{C}$ and at the flow rate of $1400 \mathrm{ml}$. per min.

The results obtained are summarized as follows;

1) It was found that massive vapor deposited coatings of beta silicon carbide were obtained already under proper control of conditions on graphite substrates at the temperature of about $1200^{\circ} \mathrm{C}$.

2) Good adherent and metal-free $\beta-\mathrm{SiC}$ coating can be deposited at $1400^{\circ}$ to $1450^{\circ} \mathrm{C}$ from a mixture of $\mathrm{SiCl}_{4}+\mathrm{C}_{7} \mathrm{H}_{8}+\mathrm{H}_{2}$, in which the $\mathrm{SiCl}_{4}: \mathrm{C}_{7} \mathrm{H}_{8}$ ratio was maintained between $3.5: 1$ and $2.5: 1$. The layer tended to become more coarsely crystalline at the temperature up to $1450^{\circ} \mathrm{C}$ and the coating layers applied below $1350^{\circ} \mathrm{C}$ were consisted of the mixture of $\beta-\mathrm{SiC}$ and $\mathrm{Si}$.

3) At the temperature of $1400^{\circ} \mathrm{C}$, the rate of deposition of metal-free $\beta$-SiC coating layers was about $3.7 \mu$ per min.

[Received Apr. 4, 1966]

\section{1.はしがき}

化学蒸着法注在来の真空蒸着法 (spattering) としてよ く知られている物理的蒸着法と異なり, 高温での気相化 学反応，たとえば揮発性の金属八ロゲン化物，金属の有 機化合物, 炭化水素化合物などの熱分解, 水素還元およ び置換反応によって各種の基材（金属，黒鉛その他）の 表面嚆融点金属, 炭化物, 硼化物, 珪化物, 窒化物な どの蒸着層を形成させるものである.

一般にはこの方法を“Gas Plating”, “Vapor Plating”
また，単に“Vapor Deposition”とも呼んでいるが,前記 の物理的蒸着と区別するために 1962 年には J. Blocher, J. Oxley ら の名称を正式の学術用語として使用することが提案され ている.

また, 最近ではこの新しい技術は各種基材の表面にお ける金属あるいは非金属材料のコーティングのみならず 気相から結晶を成長させるとき配向性をもった単結晶の 成長, すなわちエピタキシャル成長(Epitaxial growth) 
を利用した各種の元素および化合物などの蒸着皮膜によ る半導体の製造にも用いられるようになった.

著者らが本研究 ${ }^{10)}$ に着手するに至った端緒は，地球観 測年ロケットノズルの耐熱コーティングとして着手され たもので, 実験室用の小型の化学蒸着装置を試作し, 固 体燃料によるロケット噴射ノズル(黒鉛基材)の表面に炭 化珪素の被覆を施して炭素および黒鉛のもっとも大きな 欠点とされている高温での耐酸化性, 耐蝕性および耐摩 性などの向上を図ることを目的としたものである。

最近のアメリカではセラミック核燃料の表面処理法と しての新しい応用も見い出され，これに関する幾多の報 文が発表されている。とくに化学蒸着法でセラミック核 燃料 $\left(\mathrm{UO}_{2}, \mathrm{UC}, \mathrm{ZrC}, \mathrm{PuO}_{2}\right.$ など)の表面に $\mathrm{Al}_{2} \mathrm{O}_{3}, \mathrm{SiC}$ 㧍よび熱分解黒鉛 (pyrolytic graphite) のガス不渗透性 耐熱皮膜を施し，高速中性子の照射による際の fission products の発生に対する防護の目的などにも利用され ている。

一般に化学蒸着法を利用した黒鉛基材に対する炭化珪 素の被覆は，(1) シリコンの八ロゲン化物をガス状態 で，高温に保持した黒鉛基材の周囲に導入し，熱分解， 水素還元あるい社基材からの炭素の拡散を利用して行な ら方法，(2) シリコンの八ロゲン化物と八イドロカーボ ンとの混合気体を反応ガスとして用い，気相反応によ。 て加熱された黒鉛の表面に直接, 炭化珪素を析出する方 法などがある。

前者ではその析出速度は炭化珪素の皮膜を通して行な われる炭素の拡散速度によって左右される。しかし, 後 者は直接炭化珪素を析出するため, 析出速度が速く, ま た，蒸着条件の設定が容易であるなどの利点がある。

黒鉛基材の表面に炭化珪素を被覆する研究は今世紀の 始めごろ,すでに Pring, Fielding ら ${ }^{2)}$ にって $\mathrm{SiCl}_{4}+$ $\mathrm{C}_{6} \mathrm{H}_{6}+\mathrm{H}_{2}$ 系の反応ガスを用い， $1700^{\circ} \sim 2400^{\circ} \mathrm{C}$ に保持 した黒鉛のフィラメントの表面に炭化珪素を析出する研 究を試み、その先駆をなした Powell，Campbell， Gonser ${ }^{3), 4)}$ は $\mathrm{SiCl}_{4}+\mathrm{C}_{7} \mathrm{H}_{8}+\mathrm{H}_{2}$ 系の反応ガスを用い， また，Kendall ${ }^{5}$ は同様な反応ガスにより，最近では Moreton ${ }^{6}$ は $\mathrm{SiCl}_{4}+\mathrm{C}_{6} \mathrm{H}_{14}+\mathrm{H}_{2}$ 系の混合ガスを用いて 加熱した黒鉛の表面に炭化珪素の被覆を実施している。 Blocherら 2) は $\mathrm{SiI}_{4}-\mathrm{SiBr}_{4}-\mathrm{H}_{2}$ 系の反応ガスを用いて実 験を行ない，炭化珪素のみによるコーティングの安定領 域を求め，単一組成の八ロゲン化物を用いる場合よりも 蒝着条件が容易となり，その析出速度を早めることがで きることなどを報告している．

これらの化学蒸着法によるコーティングの機構はかな り複雑で, 原料として用いる反応ガスのモル比, 基材の 加熱温度 (反応温度), 蒸着時間などの諸条件によって析 出結晶相, 析出速度など結晶の成長条件に著しい影響を およぼすが，わが国ではこれまでそれらの詳細について
はほとんど系統的な研究がなされていない有様である。

本研究では反応ガスの原料として四塩化珪素，トルエ ンを，また，キャリヤーガスとして水素を用いて黒鉛基 材の表面に炭化珪素のコーティングを施す場合の反応ガ スのモル比，反応温度および蒸着時間などの諸条件が析 出結晶相におよぼす影響を調べ，高温気相反応による炭 化珪素 $(\beta-\mathrm{SiC})$ 皮膜の生成の安定領域を設定し, 耐熱 コーティング (refractory coating) の実際の工業的応用 に関する基礎資料を提供した。

\section{2. 化学蒸着装置}

著者らが試作した実験装置は図-1 に示すよらに，キ ヤリヤーガスの精製部分, 反応ガス発生部分ならびに高 周波誘導加熱に上る反応炉とから構成されている。

実験用の反応ガスについてはシリコンの臭化物, 沃化 物，塩化物などがあるがそのうち臭化物，沃化物などは 市販品として入手困難で，高価であるので工業的の原料 としては適当でない。これに較べて四塩化珪素は高純度 の原料が比較的容易に入手でき，乙かも他のものに較心゙ て安価であるので，本研究では主としてこれを採用し， ハイドロカーボンとしては, メタン，プロパン，ベンゼ ン，トルエン，へキサンなどいずれでもよいが，本実験 ではとくにトルエンを用いることとした．

さらに，この実験のように開管方式の場合のは一般に 四塩化珪素,トルエンの蒸気を水素ガスにのせて輸送す るのであるが，その場合水素ガスを気泡として溶液中に 吹込む方法と，これらの溶液の表面を通過させる方法と がある. 前者の方法は水素ガスの流量の変動が反応ガス のモル比に著しく影響し, 蒸着後の表面の粗さは水素ガ スと反応ガスの成分比に大きく関係するので，平滑な蒸 着面を得るためには $\mathrm{SiCl}_{4}+\mathrm{C}_{7} \mathrm{H}_{8} / \mathrm{H}_{2}$ の濃度を数 \% 以 下に押さえる必要がある。また，前者の方法を採用する 場合には上記の条件を満たすために，四塩化珪素の恒温 槽を零度以下に保持する必要があるので，著者らの研究 では主として後者の方法を採用することとした．

反応ガスのモル比の制御方法として (1) 四塩化珪素,

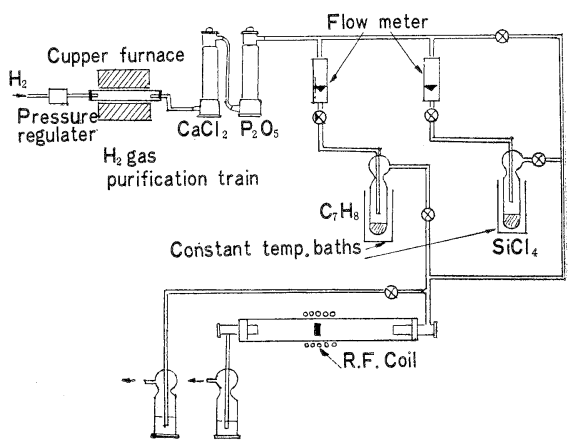

Fig. 1. Schematic diagram of silicon carbide deposition apparatus. 


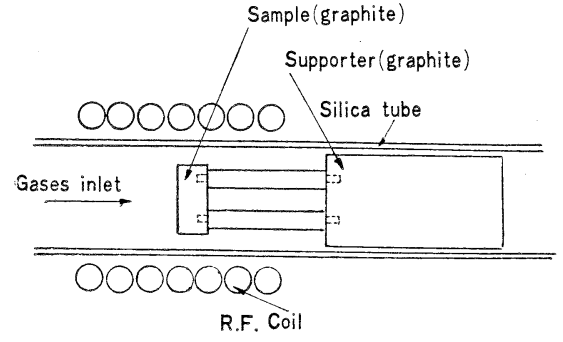

Fig. 2. Furnace and sample holder.

マルエンなどの溶液を充填した容器の恒温槽を同一温度 とし, キャリヤーガスの流量を変化させる方法, (2) キ ヤリヤーガスの流量を一定とし, 恒温槽の温度を変化す る方法，(3) 再者を併用した方法などがあるが，本実験 では，(2）の方法を用いて反応ガスのモル比の制御を行 なった。

試料の支持は図 -2 に示すような黒鉛質の 試料支持台 を作り，高周波コイルならびに石英管の中心部に設置で きるように設計し, 基材の温度は石英管の端の硯き空か ら光温度計によって蒸着面の温度を直接に測定した。

\section{3. 実 験 結 果}

著者らの研究には，黒鉛基材として日本カーボン製の $\mathrm{EG}-5,24 \phi \times 10 \mathrm{~mm}$ の平板を用い，試料の作製は次の 組成範囲の下で蒸着を行なった.すなわち反応ガスのモ ル比 $\mathrm{SiCl}_{4} / \mathrm{C}_{7} \mathrm{H}_{8}=5.0 \sim 1.3, \mathrm{SiCl}_{4}$ の濃度 $4.3 \times 10^{-4} \sim$ $1.8 \times 10^{-4} \mathrm{~mol} / \mathrm{min}$, キャリヤーガスの流量 $700 \mathrm{cc} / \mathrm{min}$, $\mathrm{C}_{7} \mathrm{H}_{8}$ の濃度 $1.4 \times 10^{-4} \sim 0.67 \times 10^{-4} \mathrm{~mol} / \mathrm{min}$ ，キャリヤ 一ガスの流量 $700 \mathrm{cc} / \mathrm{min}$, 反応温度は $1200^{\circ} \sim 1500^{\circ} \mathrm{C}$, 蒸着時間は 5 60 分, なお, 反応管に導入する水素ガス つ流量は $1400 \mathrm{cc} / \mathrm{min}$ に一定してそれぞれ実験を行なっ た.

\section{1 結晶の析出速度}

炭化珪素結晶の析出速度は蒸着前後の重量差, ならび

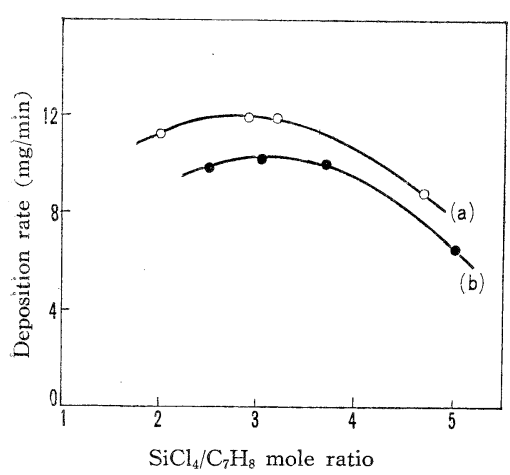

Fig. 3. Deposition rate as a function of $\mathrm{SiCl}_{4} / \mathrm{C}_{7} \mathrm{H}_{8}$ mole ratio at $1400^{\circ} \mathrm{C}$.

a) $\mathrm{SiCl}_{4}$ concentration of $4.3 \times 10^{-4}$ $\mathrm{mol} / \mathrm{min}$.

b) $3.4 \times 10^{-4} \mathrm{~mol} / \mathrm{min}$. したものであ る. $\mathrm{SiCl}_{4}$ の 濃度は $4.3 \times$
$10^{-4} \mathrm{~mol} / \mathrm{min}, 3.4 \times 10^{-4} \mathrm{~mol} / \mathrm{min}$ の 2 種類とし, 黒鉛 基材の温度は $1400^{\circ} \mathrm{C}$, 繁着時間 15 分間一定として, 反 応ガスのモル比を変えて行なった場合の実験結果であ る.

この結果によると炭化珪素の析出速度はいずれの場合 にも反応ガスのモル比が減少するとともに, 次第に増加 し, モル比 3.0 付近で極大值を示し, 以後モル比の減少 とともに潮次低下する傾向にあることを見い出した。

それらのうち, 極大值を示した蒸着条件としては, 反 応温度 $1400^{\circ} \mathrm{C}$, 反応ガスのモル比 $3.0, \mathrm{SiCl}_{4}$ の濃度 4.3 $\times 10^{-4} \mathrm{~mol} / \mathrm{min}, \mathrm{C}_{7} \mathrm{H}_{8}$ の濃度 $1.4 \times 10^{-4} \mathrm{~mol} / \mathrm{min}$ の下

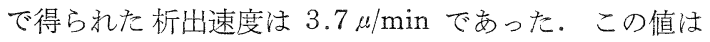
J. Blocher が $\mathrm{SiI}_{4}+\mathrm{SiBr}_{4}+\mathrm{H}_{2}$ 系の反応ガスを用いて 黒鉛基材の表 面に炭化珪素 のコーティン グを試みた実 験において得 た析出速度 $0.4 \mu / \min$ の 10倍程度の速 い析出速度で あることが判 明した。

図一 4 は結 晶の析出速度

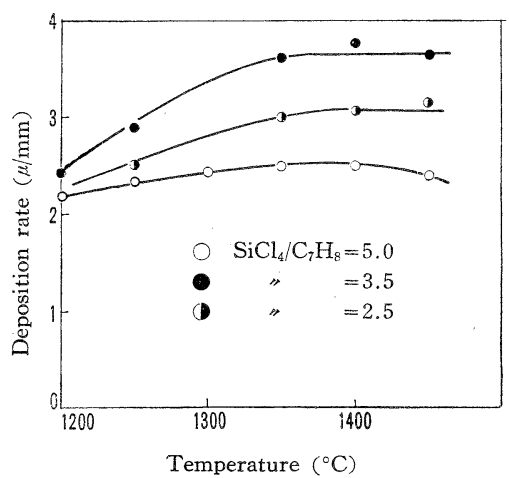

Fig. 4. Deposition rate as a function of temperature.
におよぼす反応温度の影響を示したものである，反态ガ スのモル比 $5.0\left(\mathrm{SiCl}_{4} 3.4 \times 10^{-4} \mathrm{~mol} / \mathrm{min}, \mathrm{C}_{7} \mathrm{H}_{8} 0.67 \times\right.$ $\left.10^{-4} \mathrm{~mol} \mathrm{~min}\right), 3.5\left(\mathrm{SiCl}_{4} 4.3 \times 10^{-4} \mathrm{~mol} / \mathrm{min}, \mathrm{C}_{7} \mathrm{H}_{8} 1.23\right.$ $\left.\times 10^{-4} \mathrm{~mol} / \mathrm{min}\right), 2.5\left(\mathrm{SiCl}_{4} 3.4 \times 10^{-4} \mathrm{~mol} / \mathrm{min}, \mathrm{C}_{7} \mathrm{H}_{8}\right.$ $\left.1.35 \times 10^{-4} \mathrm{~mol} / \mathrm{min}\right)$ の 3 種類を用い, 蒸着時間は 15 分 間とし反応温度を変化した場合の結果である。いずれの 場合においても反応温度の上昇とともに析出速度は増加 するが， $1400^{\circ} \mathrm{C}$ 付 近から飽和の傾向を 示したが,モル比 5.0 の場合注 $1400^{\circ} \mathrm{C}$ 以上でやや減少す る.

図-5, 6 には重量 変化におよぼす反応 時間の影響について 示した。図 -5 は反 店ガスのモル比 3.5 ( $\mathrm{SiCl}_{4} 4.3 \times 10^{-4} \mathrm{~mol}$ $/ \min ), \quad\left(\mathrm{C}_{7} \mathrm{H}_{8} 1.23\right.$

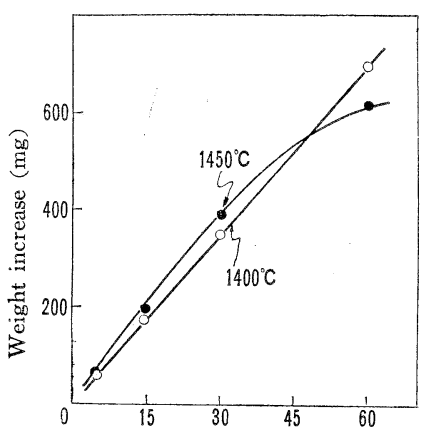

Vapor deposition time (min)

Fig. 5. Weight change as a function of vapor deposition time. $\left.\times 10^{-4} \mathrm{~mol} / \mathrm{min}\right)$ ，一定で反応温度 $1400^{\circ} \mathrm{C}, 1450^{\circ} \mathrm{C}$, 図 -6 は $2.5\left(\mathrm{SiCl}_{4} 3.4 \times 10^{-4} \mathrm{~mol} / \mathrm{min}, \mathrm{C}_{7} \mathrm{H}_{8} 1.35 \times 10^{-4}\right.$ 
$\mathrm{mol} / \mathrm{min})$, 一定で反 応温度 $1400^{\circ} \mathrm{C}, 1450$ ${ }^{\circ} \mathrm{C}$ における蒸着時間 を変化した場合の実 験結果である。反応 温度が $1400^{\circ} \mathrm{C}$ の場 合，重量増加は時間 とともにほぼ直線的 に増加しているが， 反応温度が $1450^{\circ} \mathrm{C}$

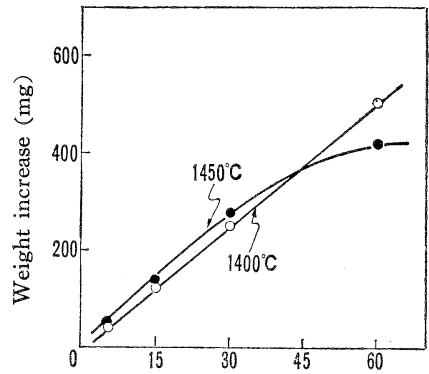

Vapor deposition time ( $\mathrm{min}$ ) 以上,蒸着時間 30 分 Fig. 6. Weight change as a function 以上になると直線性 of vapor deposition time.

からずれるよらな傾向を示した。

\section{$3.2 \mathrm{X}$ 線による観察}

前記の条件で黒鉛基材の表面に蒸着した各試料の皮膜 亿直接X線を照射し，反応ガスのモル比，反応温度，反 応時間が析出結晶相におよぼす影響を調心゙，炭化珪素の みによる安定領域を求めたが，前記の実験条件で蒸着を 行なった場合の試料はいずれも等軸晶系の $\beta$ 型炭化珪素 であることが明らかとなった。

図-7 法応温度 $1200^{\circ} \mathrm{C}$, 蒸着時間 15 分に一定し, 反 応ガスのモル比が $4.7\left(\mathrm{SiCl}_{4} 4.3 \times 10^{-4} \mathrm{~mol} / \mathrm{min}, \mathrm{C}_{7} \mathrm{H}_{8}\right.$ $\left.0.91 \times 10^{-4} \mathrm{~mol} / \mathrm{min}\right), \quad 3.5\left(\mathrm{SiCl}_{4} 4.3 \times 10^{-4} \mathrm{~mol} / \mathrm{min}\right.$, $\left.\mathrm{C}_{7} \mathrm{H}_{8} 1.23 \times 10^{-4} \mathrm{~mol} / \mathrm{min}\right), 2.5\left(\mathrm{SiCl}_{4} 3.4 \times 10^{-4} \mathrm{~mol} /\right.$ $\left.\min , \mathrm{C}_{7} \mathrm{H}_{8} 1.35 \times 10^{-4} \mathrm{~mol} / \mathrm{min}\right)$ の条件でそれぞれ実験 した場合の各試料のX線回折像で，すでにこの温度で， $\beta-\mathrm{SiC}$ の結晶が析出するが， $\beta-\mathrm{SiC}$ 以外には金属珪素 (Si) およびカーボンの析出が認められた。

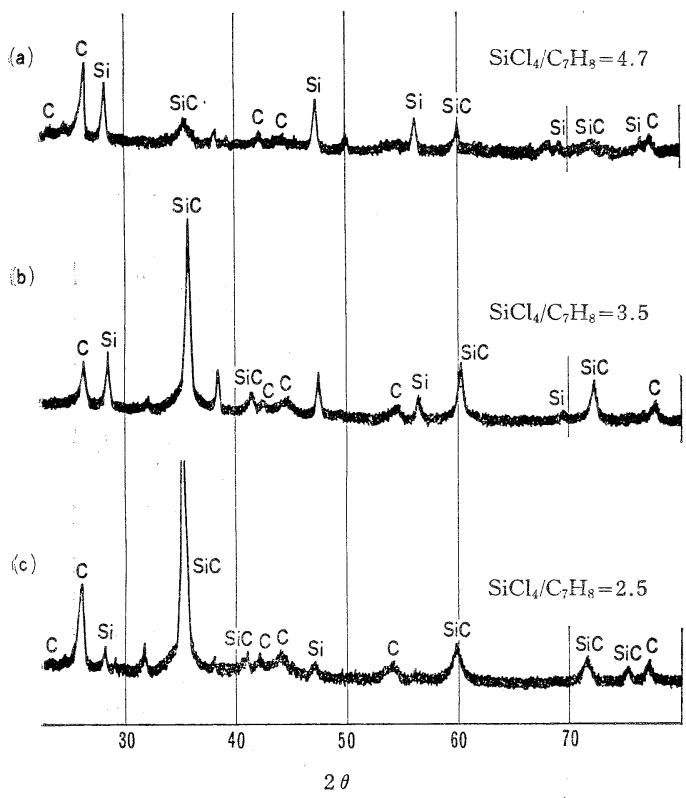

Fig. 7. X-ray diffraction pattern of vapor deposition layers in the system $\mathrm{SiCl}_{4}+\mathrm{C}_{7} \mathrm{H}_{8}+\mathrm{H}_{2}$ by heating at $1200^{\circ} \mathrm{C}$ for 15 minutes.
その結果では金属珪素の回折線の強度はモル比が增加 するとともに強くなり，その反面 $\beta-\mathrm{SiC}$ の回折強度は 低下し，反応ガスのモル比が増大するとともに珪素が多 量に析出すること，また，珪素の析出は反応温度が上昇 するとともに減少し， $1400^{\circ} \mathrm{C}$ 以上の温度ではほとんど 認められなかったが，モル比が 5.0 以上の場合 $1450^{\circ} \mathrm{C}$ の高温においても珪素が析出する傾向があることなどを 見い出した。なお，図-8 はモル比 5.0 , 反応温度 $1450^{\circ} \mathrm{C}$ 蒸着時間30分の蒸着条件で行なった試料のX線回折図で ある・

反応ガスとして用いた四塩化珪素 $\left(\mathrm{SiCl}_{4}\right)$ ，トルエン $\left(\mathrm{C}_{7} \mathrm{H}_{8}\right)$ の化合物中の珪素とカーボンとがずてて応に 寄与したと仮定するならば, $\mathrm{SiCl}_{4}: \mathrm{C}_{7} \mathrm{H}_{8}$ のモル比 7 : 1 以上の場合に珪素が析出するはずであるにもかかわら ず，この值から低い值のときでも珪素が析出すること， また，炭素は反応ガスのモル比，反応温度には関係なく 蒸着時間が短かい場合にのみ析出する傾向にあることな どがそれぞれ確認された。

罒-9, 10 はその一例を示したもので，反忘ガスのモル 比 $3.2\left(\mathrm{SiCl}_{4} 4.3 \times 10^{-4} \mathrm{~mol} / \mathrm{min}, \mathrm{C}_{7} \mathrm{H}_{8} 1.34 \times 10^{-4} \mathrm{~mol} /\right.$ $\min$ ), 反応温度は $1400^{\circ} \mathrm{C}$ に一定し，反応時間 5 分， 30 分の条件で蒸着した試料のX線回折図で，これらの実験 では蒸着時間が長い場合の試料ではカーボンの析出は認 められないが，蒸着時間が短い場合は図-10 に示すよう にカーボンの析出が認められた。

このようにカーボンの析出は反応ガスのモル比, 反応 温度に関係なく蒸着時間に影響すること, すなわち蒸着

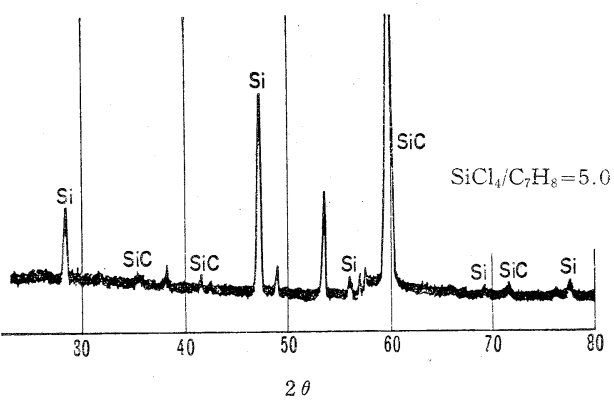

Fig. 8. X-ray diffraction pattern of vapor deposition layers in the system $\mathrm{SiCl}_{4}+\mathrm{C}_{7} \mathrm{H}_{8}+\mathrm{H}_{2}$ at $1450^{\circ} \mathrm{C}$ for 30 minutes.

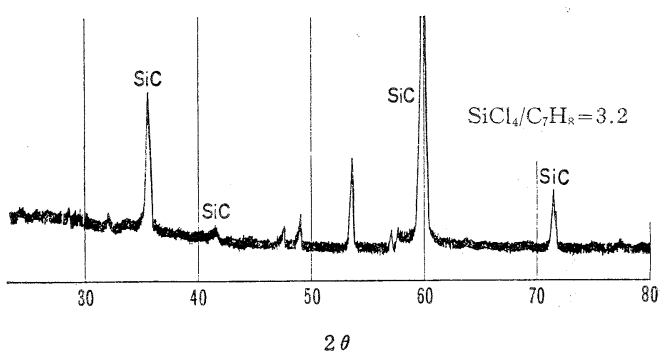

Fig. 9. X-ray diffraction pattern of vapor deposition layers at $1400^{\circ} \mathrm{C}$ for 5 minutes. 


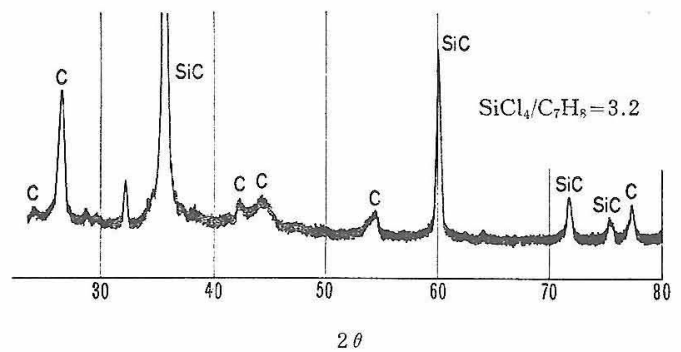

Fig. 10. X-ray diffraction pattern of vapor deposition layers at $1400^{\circ} \mathrm{C}$ for 30 minutes.

層の厚さに関連があることを暗示するもので，蒸着時間 が短か、場合，カーボンが析出するのは黒鉛基材からの カーボンの拡散によるものと推測される.

さらに金属珪素注反応ガスのモル比に関倸なく，反応 温度が $1400^{\circ} \mathrm{C}$ 以下の蒸着条件の場合に析出するがモル 比が 5.0 付近より增大寸ると $1400^{\circ} \mathrm{C}$ 以上の温度でも析 出することがそれぞれ明らかとなった。

本実験でとくに興味あることは，図-11 に示したよら にその蒸着条件によって $\beta$-SiC の (111) 面，あるいは (220) 面の回折線が強調され，その蒸着面では結晶が著 しい配向性を有していることである。

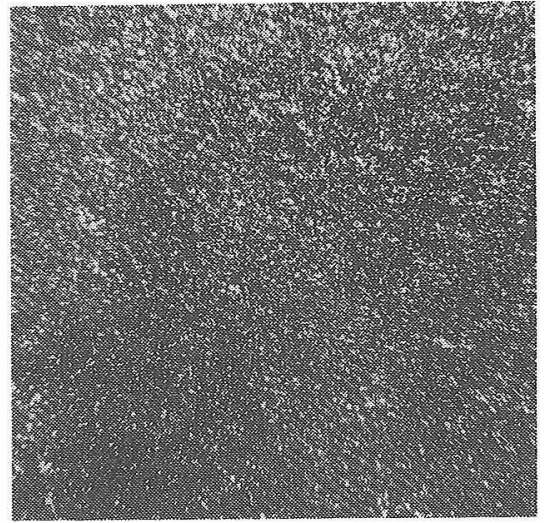

(a) $1400^{\circ} \mathrm{C}(\times 50)$

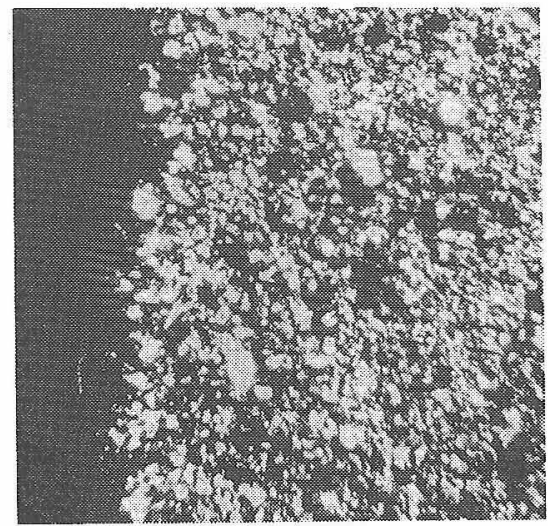

(b) $1500^{\circ} \mathrm{C}(\times 50)$

Fig 12. Optical micro-photographs of the surface of $\beta$ - $\mathrm{SiC}$ coated layers. (a)

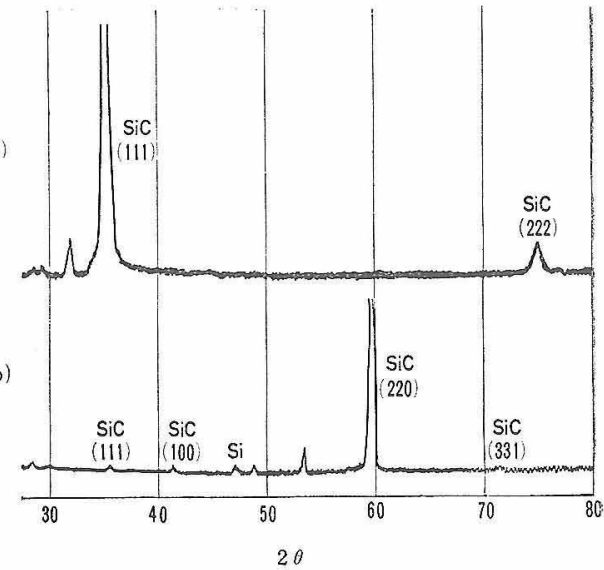

Fig. 11. X-ray diffraction pattern of deposition layers (a) at $1450^{\circ} \mathrm{C}$ for 5 minutes and $\mathrm{SiCl}_{4} / \mathrm{C}_{7} \mathrm{H}_{8}$ ratio of 2.5 (b) at $1450^{\circ} \mathrm{C}$ for 60 minutes and $\mathrm{SiCl}_{4} / \mathrm{C}_{7} \mathrm{H}_{8}$ ratio of 4.7 .

\section{3 蒸着面の観察}

これらの蒸着面の粗度は反応温度, 反応時間, 反忘力゙ スのモル比によってもかなり影響される。

図-12,13 は反応ガスのモル比, 反応温度が烝着面の

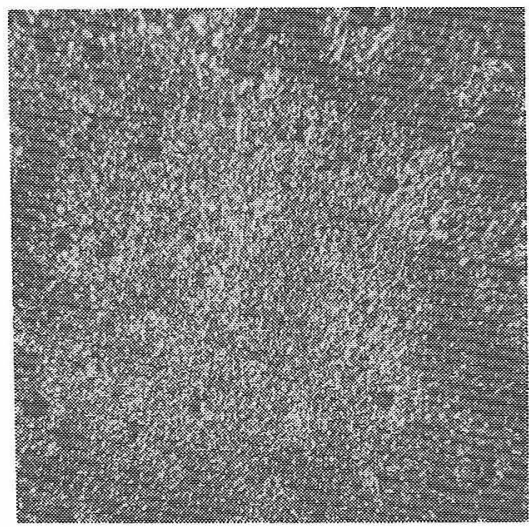

(a) $1400^{\circ} \mathrm{C}(\times 50)$

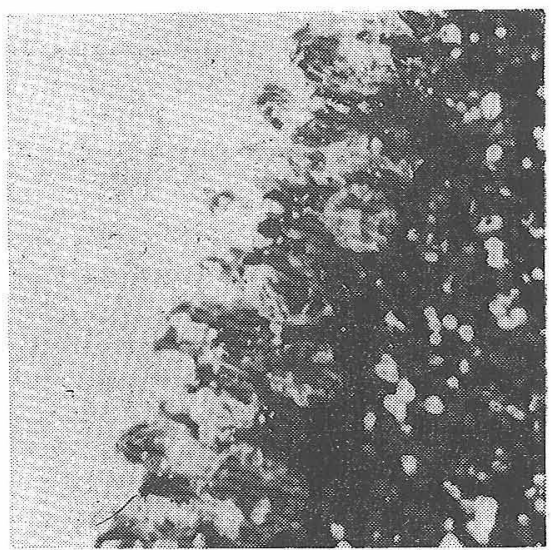

(b) $1500^{\circ} \mathrm{C}(\times 50)$

Fig. 13. Optical micro-photographs of the surface of $\beta$-SiC coated layers. 
粮度におよぼす影響を示した写真の一例である。図-12 (a), (b) 汳応ガスのモル比 3.5 , 反応時間 15 分と一定 し, 反応温度 $1400^{\circ} \mathrm{C}, 1500^{\circ} \mathrm{C}$ の条件で行なった場合の蒸 着面, 図-13 (a), (b) は反応ガスのモル比 2.5 , 反応時 間 15 分と一定し, 反応温度 $1400^{\circ} \mathrm{C}, 1500^{\circ} \mathrm{C}$ の条件で行な った試料の蒸着面の状況を示した写真である。いずれの 場合でも，反応温度が上昇した場合にはその蒸着面が粗 く，また,反応ガスのモル比が減少した場合には $1400^{\circ} \mathrm{C}$ では，反応ガスのモル比の影響はあまり見られないが $1500^{\circ} \mathrm{C}$ では戝に見られるように表面から柱状に顕著に 発達した結晶が認为られた。

析出結晶の重量増加と蒸着時間との関倸に㧈いて図一 5,6 に見ら机る上うに黒鉛基材の温度 $1450^{\circ} \mathrm{C}$ 以上，蒸 着時間が 30 分以上になると, 析出結晶の重量増加が直 線的関係から偏倚するのはこの結晶の発達との関連, す なわち, 加熱方式が高周波誘導によっているため, 試料 自体の材質的変化 $(\beta-\mathrm{SiC}, \mathrm{C})$ による温度差に起因する ためと考えられる。

\section{4. 実験結果の考察}

本研究では高温における気相反応, すなわち $\mathrm{SiCl}_{4}+$ $\mathrm{C}_{7} \mathrm{H}_{8}+\mathrm{H}_{2}$ 系の反応ガスを用いて黒鉛基材の表面に炭化 珪素をコーティングする場合の反応ガスのモル比, 反応 温度, 蒸着時間などの各蒸着条件を検討し, $\beta-\mathrm{SiC}$ の単 一成分の析出する安定領域を実験的に求內た。この化学 蒸着による $\beta-\mathrm{SiC}$ の生成機構を解明するためには高温 に招ける $\mathrm{SiCl}_{4}, \mathrm{C}_{7} \mathrm{H}_{8}$ の状態について考察する必要があ る。この反応機構についてはまだ十分に解明されていな 以.

最近，Warschauer ${ }^{8)}$ は $\mathrm{SiCl}_{4}+\mathrm{H}_{2}$ 系の反応ガスを用 いて黑鉛基材の表面に $\mathrm{SiC}$ を生成する場合, $\mathrm{SiCl}_{4}$ は水 素還元により $\mathrm{SiCl}_{2}$ を生成

$$
\mathrm{SiCl}_{4}+\mathrm{H}_{2} \rightarrow \mathrm{SiCl}_{2}+2 \mathrm{HCl}
$$

また，黒鉛基材と $\mathrm{H}_{2}$ との反応によりメタンを生成

$$
\mathrm{C}+2 \mathrm{H}_{2} \rightarrow \mathrm{CH}_{4}
$$

$\mathrm{SiCl}_{2}$ と $\mathrm{CH}_{4}$ との反応により $\mathrm{SiC}$ を生成することを 報告している。

$$
\mathrm{SiCl}_{2}+\mathrm{CH}_{4} \rightarrow \mathrm{SiC}+2 \mathrm{HCl}+\mathrm{H}_{2}
$$

本実験の場合 $\mathrm{SiCl}_{4}+\mathrm{H}_{2}$ 以外にトルエンを加えてい るので, 当然上記のような反応が同時に起こることが予 測される。

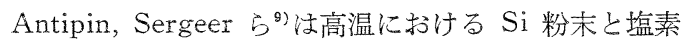
ガスとの反応を調べるため, 反応生成物の $\mathrm{Cl} / \mathrm{Si}$ の比率 を実測し， $1000^{\circ} \mathrm{C}$ 亿扔いては $\mathrm{SiCl}_{4}$ が生成され，さら に温度が上昇すると生成物の $\mathrm{Cl} / \mathrm{Si}$ の比率法徐々に低下 し, $1350^{\circ} \mathrm{C}$ 付近で $\mathrm{Cl} / \mathrm{Si}=2$ に漸近し, $1400^{\circ} \mathrm{C}$ ではほ んど $\mathrm{SiCl}_{2}\left(\mathrm{SiCl}_{4}+\mathrm{Si} \rightleftarrows 2 \mathrm{SiCl}_{2}\right)$ になることを報告して いる。この温度は先に述べたように金属珪素（Si）が析
出するか否かの境界温度に対応している。

以上の事実を考台台わせると $\beta-\mathrm{SiC}$ の析出には $\mathrm{SiCl}_{2}$ の挙動が大きな意味をもっていることが推測されるがこ れらの反応機構についてはさらに後日の実験結果をまっ て報告することとしたい。

$$
\text { むす び }
$$

著者らは高温気相反応， とくに $\mathrm{SiCl}_{4}+\mathrm{C}_{7} \mathrm{H}_{8}+\mathrm{H}_{2}$ 系 の反応ガスを用いた化学蒸着によって黒鉛基材の表面に 耐酸化, 耐蝕性の炭化珪素皮膜の生成について反応ガス のモル比, 反応温度, 蒸着時間などの諸条件が析出相に およぼす影響などについて実験的に調べた結果，次に示 すような結論を得た。

i）本実験の蒸着条件の下では析出する炭化珪素はす べて等軸晶系の $\beta$ 型のもので, 反応温度約 $1200^{\circ} \mathrm{C}$ に拧 いてすでに $\beta$-SiC が析出する事実を見い出した。

ii） $\beta-\mathrm{SiC}$ の単一成分による耐熱コーティングの安定 領域は, 反応ガスのモル比 $3.5 \sim 2.5$, 反応温度 $1400^{\circ}$ $1450^{\circ} \mathrm{C}$, 蒸着時間 15 60 分の範囲にあることがそれぞ れ明らかとなった。

なお，セラミックコーティング10) 18) のうちで，もっ とも代表的なものとしては，(1) 珐唧釉燒付けによる耐 熱珐郎，(2) 炎溶射，(3) 化学蒸着などがあげられる が, この化学蒸着法の応用はきわめて広汎で金属または 非金属基材の表面に $\mathrm{Nb}, \mathrm{Mo}, \mathrm{Cr}, \mathrm{Ni}$ ，Ta などの高融 点金属, pyrolytic carbon, $\mathrm{BN}, \mathrm{W}$ をはじめ $\mathrm{NbC}, \mathrm{SiC}$, $\mathrm{Al}_{2} \mathrm{O}_{3}, \mathrm{BeO}, \mathrm{ZrO}_{2}, \mathrm{Cr}_{2} \mathrm{O}_{3}$ その他酸化物, 炭化物, 窒化 物などの混合物による耐熱性の皮膜, 半導体などの製造 についての研究が活発に進められている。

な扮, この研究は昭和 38 年〜39 年文部省科学研究費（試験 研究）奴東京工業大学協同研究費の補助を得たことを記し， 併せて試料との他の御援助をいただいた日本カーボン（株）に対 して心から感謝する次第である.

\section{文献}

1) J.M. Blocher, J.H. Oxley, Am.Ceram. Soc. Bulletin, 41, 2 (1962).

2) J.N. Pring, W. Fielding, J. Chem. Soc. 95, 1497 (1909).

3) I.E. Campbell, C.F. Powell, D.H. Nowichi, B.W. Gonser, J. Electrochem. Soc. 96 [5] 318 (1949).

4) C.F. Powell, I.E. Campbell and B.W. Gonser, "Vapor-Plating", John Wiley \& Sons, Inc., New York, 158 pp. (1955).

5) J.T. Kendall, J. Chem. Phys. 21, 821 (1953).

6) R. Moreton, Special Ceramics 61 (1964).

7) J.M. Blocher, D.P. Leiter, Battele Memorial Inst. Rep. No. BMI-1349 (1959).

8) D.M. Warschauer, Raytheon Company Rep. AF 19 (604)-6133 (1960).

9) P.F. Antipin, V.V. Sergeer, J. Apply Chem. 27 [2] 737 (1954).

10）河嶋千尋, 村田順弘, 東大生産技研, 生産研究 8, 6 (1956).

11）河嶋千尋, 村田順弘, 窯協 65 ［735］31 40（1957）；68 
C 298 C 304 (1960).

12）河嶋千尋, 村田順弘, 瀬高信雄, 窯協 66 [12] 281 86 (1958).

13) 河嶋千尋, 日本航空学会 8 [77]； 8 [79] (1960).

14) 河嶋千尋, 村田順弘, 工化 63 [7] (1960).

15）河嶋千尋，瀬高信雄，金属表面技術 14, 8 （1963）。
16）河嶋千尋, 瀬高信雄, 第 3 回窝業基礎討論会講演要旨集 (1965).

17）河嶋千尋, 瀬高信雄, 第 10 回人工鉱物討論会講演要旨集 (1965).

18）河嶋千尋, 瀬高信雄, 第 4 回窯業基礎討論会講演要旨集 (1966).

\title{
ポルトランドセメントおよびその構成鉱物の \\ 水和におよぼすサッカロース, $\boldsymbol{d}-$ グリコ \\ ース，デキストリンなどの影響
}

田中弘文・村上恵一・小烃忠明

(東北大学工学部)

\section{Influences of Succharose, d-Glucose and Dextrin on the Hydration of Portand Cement and its Clinker Minerals}

\author{
By \\ Hirobumi TANAKA, Keiichi MURAKAMI and Tadaaki KOMATSU \\ (Faculty of Engineering, Tohoku University, Sendai)
}

\begin{abstract}
It has been well known that some carbohydrates have a injurious effect on the hydration of portland cement. Succharose, for example, acts as a retarder when present in low concentrations, but accelerates set (temporarily occurs the flash set in the strict sence of the word) when used at higher concentrations. Moreover, the development of the compressive and bending strength is lowered with the increase of the concentration of succharose, and the hardening of portland cement mortar and concrete are impossible over a few months in such higher concentrations as the flash set happens.

There are many reports about the above mentioned actions of succharose on the hydration of portland cement, but is something to be investigate.

Authors investigated the hydration of portland cement and clinker minerals from several points of view in the presence of succharose, $d$-glucose and dextrin, and obtained the results as following.

(1) Influences of $d$-glucose on the setting and hardening of portland cement are similar to that of succharose, and dextrin has also slightly similar action to the latters.

(2) The possible explanation of the flash set, which occur in higher concentrations of succharose, may be that a large amounts of gel-like lime-ssuccharose compound and aluminum hydroxide are produced by chemical reaction between succharose and tricalcium aluminate and occurs "gel set" by sudden coagulation.

The precipitation of insoluble compounds, which may be trilime-monosuccharate and higherlime-monosuccharate produced by the reaction between succharose and surface of alite particle and lime in a aq. solution, plays an important role in retarding the development of mechanical strength.

The retarding action of succharose and $d$-glucose etc. on the hydration of alite increase consistently with the increse of its concentrations.

(3) $\alpha$-d-methylglucosid, which is produced by the reaction of $\mathrm{H}_{3} \mathrm{C}$ - with "reducing carbon" group of glucose, does not react with lime, therefore, has only a little effect on the hydration of portland cement clinker minerals in relatively higher concentrations.
\end{abstract}

(4) The mechanism of the hydration of alite, with or without carbohydrate, are investigated by the analyzing of the heat liberation curves which were derived from hydration of alite in devised adiabatic calorimeter. The proposed 